\author{
Department of Economics \\ and \\ Institute for Policy Analysis \\ University of Toronto \\ 150 St. George St. \\ Toronto, Canada \\ M5S 1A1 \\ WORKING PAPER \\ NUMBER UT-ECIPA-SMART-96-02
}

\title{
On limited liability and the development of capital markets: An historical analysis*
}

\author{
Michael Smart \\ Department of Economics \\ University of Toronto
}

June 27, 1996
Copyright 1996by Michael Smart
Department of Economics
University of Toronto
ISSN 0829-4909

Author's email: msmart@chass.utoronto.ca

On-line Version: http://www.epas.utoronto.ca:8080/ecipa/wpa.html 


\begin{abstract}
We study the consequences of the introduction of widespread limited liability for corporations, with particular reference to the liability reforms introduced in Great Britain during the nineteenth century. In the view that is most widely accepted, by reducing transactions costs associated with screening and monitoring in capital markets, limited liability increases efficiency of capital markets and enhances investment incentives for individuals and firms. But the standard transaction-cost perspective does not explain several important stylized facts of the British experience, including the slow rate of adoption of limited liability by firms in the years following legal reforms. We construct an alternative model of asymmetric information and default in credit markets that accounts for this and other features of the British experience. In the model, a firm's decision to adopt limited liability may be interpreted in equilibrium as a signal the firm is more likely to default. Hence less risky firms may choose unlimited liability or forego investments entirely. We show the model may have multiple, Pareto-rankable equilibria in which different proportions of the firms choose to incorporate with limited liability and different levels of aggregate investment result. Thus the choice of liability rule can lead to "development traps," in which profitable investments are not undertaken, through its effect on equilibrium beliefs of uninformed investors in the economy. We apply the theory to a data set describing the first English firms to incorporate after the legislative reforms of 1856 .
\end{abstract}

Journal of Economic Literature Classification Numbers: K2,N2,G3

${ }^{*}$ Thanks to Avner Greif and Aloysius Siow for helpful comments. Financial support from a Sloan Foundation Dissertation Fellowship is gratefully acknowledged. 


\section{Introduction}

The institution of limited liability for firms has typically been regarded as one of the most important innovations of the late Industrial Revolution era. This view was aptly, if somewhat effusively, expressed by one early commentator, who stated

The limited liability corporation is the greatest single discovery of modern times.... Even steam and electricity are far less important.... ${ }^{1}$

In the view that is perhaps now most widely accepted, the transfer of risk from shareholders to creditors associated with the adoption of limited liability has no first-order effect on a firm's cost of capital or level of investment. Such transfers, it is argued, should be fully compensated in equilibrium by the risk premium on a corporate firm's debt. Thus limited liability was not a boon to equity investors, nor did it reduce the cost of capital for firms. Instead, it is frequently argued, liability rules influence the aggregate level of transaction costs - particularly costs of screening applicants for capital and monitoring their subsequent behaviour - associated with a given level of investment. Limited liability was successful, in this view, because it effectively minimized transaction costs in the emerging capital markets of the nineteenth century.

This perspective on the incorporation decision leaves unexplained a number of facts about the historical experience with liability reform, in Great Britain and elsewhere. In particular, British firms were apparently slow to incorporate following the liability reforms of 1856; most large-scale firms in many industries continued to rely on private and internal sources of finance until the end of the century. The analysis also raises questions of the timing of liability reform, which occurred later in Great Britain than in the United States and elsewhere in Europe. This suggests that any analysis of limited liability must seek to answer two classes of questions. First, what were the effects of limited liability legislation on nineteenth-century capital markets? Second, why had unlimited liability previously been the norm, and why did the change in liability rules occur when it did, in Great Britain and elsewhere?

In this paper, we argue that, contrary to the transaction-cost perspective, a liability rule can indeed influence the equilibrium capital allocation, through its effects on information processing and adverse selection in capital markets. By making it easier and cheaper for firms to obtain limited liability, legislative changes improved the average quality of firms issuing limited liability securities. This in turn attenuated default and malfeasance and reduced the cost of capital for these firms. Thus, while we focus on the transaction and information costs associated with liability rules, we study cases in which the efficiency of capital market equilibrium depends on transaction costs, through their effects on which projects are funded and which are not. In contrast, the transaction-cost school takes equilibrium as efficient, given the level of transaction costs, and studies how institutional changes affect the aggregate level of such costs. These two approaches give rise to markedly different conclusions about the importance of liability rules.

The two approaches also lead to different explanations of the delayed adoption of limited liability in Great Britain. In the view of the transaction-cost school, limited liability was opposed by many important industrialists of the era because it was understood

\footnotetext{
${ }^{1}$ N.M. Butler, President of Columbia University, 1911. (Cited in Meiners et al., 1979, 351).
} 
that unlimited liability acted as a barrier to entry, raising the cost of capital for potential competitors and protecting rents for incumbents. In the new view, opposition to liability reform - shared by many contemporary commentators, in addition to some industrialists may have reflected concerns about the external effects of adverse selection on the cost of capital for all firms.

The adverse selection approach also helps to explain why limited liability was adopted only slowly by firms in the generation following the Joint-Stock Companies Act of 1856 , and offers a new perspective on the decline in productivity and slower growth rate experienced in Britain during the "second Industrial Revolution" of the latter half of the nineteenth century. In this view, Britain's earlier successes led to a build-up of retained earnings among existing firms, decreasing their reliance on external capital markets. This leads to a greater degree of adverse selection, as more low-risk but cash-constrained firms are unable to invest.

We provide a preliminary test of the theories using data on the earliest English firms to incorporate following the liability reforms of 1856. Approximately two-thirds of jointstock companies existing at the time of the introduction of general limited liability chose to remain as unlimited liability firms. Preliminary evidence provides some support for the view that the earliest limited liability corporations represented an adverse selection. Failure rates in the years following incorporation were higher on average for limited firms in the sample, significantly so in some industries.

The plan of the paper is as follows. Section 2 reviews the existing theoretical and legal-institutional literature on limited liability. Section 3 briefly describes the British experience with liability reform in the nineteenth century and provides data on the liability choices of the earliest English firms to incorporate following the reforms of 1856 . Section 4 develops a simple alternative model of the effects of liability legislation on the degree of adverse selection in credit and equity markets. Section 5 describes the data and presents empirical results. Section 6 concludes the paper.

\section{Previous literature}

Traditionally, in historical studies, limited liability has been viewed as a necessary condition for widespread investment in joint-stock companies. In this view, equity investments in joint-stock companies over which the investor had no direct control were generally unattractive under unlimited liability. Investors were unwilling to expose their own wealth to the companies' risks, and the development of diversified equity investment was curtailed.

Together with joint-stock organization, then, limited liability has been accorded a primary role in the expansion of capital formation during the period. Thus, "accumulation and investment of capital ... was one of the outstanding achievements of the nineteenth century," (Heaton, 1948, 577) and largely due to financial innovations such as limited liability. Large quantities of capital were available following the forced saving of the Napoleonic Wars era, but could not be marshalled for investment until financial innovations - particularly limited liability — reduced the risks associated with equity investment. $^{2}$

\footnotetext{
${ }^{2}$ Payne (1978) states, "In itself, the raising of large capitals apparently did not constitute so much of a problem as that feature of English law of partnership that made each contributor fully liable for the losses of the enterprise... This was the spectre confronting all those who participated in the affairs of large
} 
A more recent, theoretical literature takes issue with this standard view of the role of limited liability, however. Adopting an efficient markets perspective, these papers argue that the traditional focus on the risk-sharing effects of liability rules is misplaced. Instead, they examine the influence of ownership and control structures and liability rules on the level of transaction costs in capital markets, typically arguing that limited liability minimizes such costs and enhances market efficiency.

In a seminal contribution, Posner (1976) observed that the shifting of risk from equity investors to creditors could not per se induce a reduction in the firm's cost of capital nor an increase in investment. While equity investors' risks of losses are limited, the probability of default on the firm's debt increases correspondingly, and creditors demand compensation in the form of a risk premium on debt interest. In equilibrium, if capital markets are perfect, ${ }^{3}$ the risk premium should exactly compensate for the transfer of default risk. Equity investors therefore receive no transfer through the choice of liability regime, and the value of the firm remains unchanged.

This view had been adopted by most subsequent authors studying liability law, and it forms the basis of their work. The notion that creditors demand a risk premium in equilibrium that reflects the increased risk of default associated with limited liability is probably no longer a matter of controversy. Posner's further inference that the value of the firm and its level of investment should be unaffected by the choice of liability rule is less straightforward, however.

In support of the Posnerian view, Halpern et al. (1980) argue that, whatever the liability status chosen by the firm, private investors can always obtain bundles of securitiesparticularly, margin loans to purchase equity that are collateralized by the shares in the firm, or explicit insurance contracts - that mimic limited liability debt and equity. ${ }^{4}$ This possibility seems to have been more than a theoretical nicety in nineteenth century England prior to liability reforms. There is indeed some evidence that such transactions were not uncommon for investors in unlimited companies. ${ }^{5}$

In perfect capital markets, then, the choice of liability rule should be irrelevant to the real decisions of the firm, its market value, and the savings decisions of individual

partnerships or unincorporated companies, and understandably there were relatively few willing to take the risk." (p. 194)

${ }^{3}$ The notion of perfect capital markets is not made explicit in the work of Posner (1976) or subsequent authors. It presumably should be taken to mean that the conditions of the Modigliani-Miller theorem are satisfied, rather than the potentially much stronger conditions for perfect Arrow-Debreu contingent claims markets.

${ }^{4}$ This logic is merely an extension of results on the irrelevance of corporate financial policy in the presence of default risk, due to Stiglitz (1969) and Hellwig (1981), which extend the standard ModiglianiMiller neutrality results established in a model without possibility of bankruptcy. When such securities are available, the firm's choice of liability status is formally irrelevant.

${ }^{5}$ In the public debate preceding the 1855 reforms, an editorial in the Economist noted

the alteration in the law, whenever effected, will be followed by far less beneficial or mischievous results than its advocates hope and its opponents dread... [I]n practice, ..., all partners contract with each other, and the company contracts with every person it deals with, that all claims shall be confined to the subscribed fund of the company. Every person with whom it deals entering voluntarily into the contract, the principle of limited liability is, by common consent, fully carried out, whatever the law may say to the contrary. (Vol. 12, July 1, 1854, pp. 698-700.) 
investors. But Posner (1976) suggested that, given the presence of significant transaction costs in capital markets - particularly costs of screening investment proposals and monitoring entrepreneurs' behaviour-liability rules may assume crucial importance for the efficiency of market equilibrium.

Posner notes that limited liability shifts risk from shareholders to creditors, which therefore imposes on creditors greater responsibility to monitor the actions of the managers of the firm. He suggests that this arrangement may be more efficient than unlimited liability if: (i) creditors are less risk averse than shareholders, or (ii) creditors are better able to monitor the firm's managers than shareholders.

A perhaps more persuasive set of arguments examines the types of transaction costs that are unique to an unlimited liability rule. ${ }^{6}$ Chief among these costs are those associated with verifying the personal wealth of equity investors under unlimited liability, and of recovering from them for debts in the event of default by the firm. Manne (1967) provided the first modern discussion of these considerations, suggesting that under an unlimited liability rule only investors that were themselves nearly insolvent could be induced to hold equity in the firm. Wealthier investors would be unwilling to invest, knowing that their eventual liability for debts could be much greater, given the insolvency of other investors.

These arguments are further developed in Halpern et al. (1980), where it is noted that, in addition to the costs of monitoring shareholder wealth, there are transaction costs associated with the default of the firm that are presumably higher under an unlimited liability regime. Creditors must pursue individual shareholders to recover debts, and issues of joint and several liability for debts must be resolved among shareholders. Presumably such costs are large, and are possibly greater than the agency costs associated with the potential for managerial malfeasance under a limited liability rule.

\section{The British experience with liability reform}

The nineteenth century saw two large-scale reforms in British company law. The Registration Act of $1844^{7}$ facilitated the widespread ownership and exchange of shares in companies, but preserved unlimited liability for equity owners. The Joint-Stock Companies Act of $1856^{8}$ permitted companies to limit the liability of equity owners for the company's debts to be no greater than their initial investment. Limited liability was to be generally available to firms for a fee - a specific act of Parliament had previously been required for each firm desiring limited status - but new disclosure requirements would be imposed on limited firms.

A puzzling feature of the British experience is the exceptionally slow development of corporate capital markets in the generation following the reforms. Heaton (1948) notes that many early firms established with limited liability were small and not particularly long-lived. Retentions remained the most important source of finance throughout the latter half of the nineteenth century. Payne (1978) also notes the importance of internal finance throughout the nineteenth century, asserting that unlimited enterprises were easily modified to share risk appropriately. There was relatively little demand for limited liability, as retained earnings and "an increasingly sensitive network of monetary intermediaries"

\footnotetext{
${ }^{6}$ Woodward (1985) provides an excellent synthesis of this class of arguments.

${ }^{7} 7-8$ Vict., c. 110

${ }^{8} 18-19$ Vict., c. 133 .
} 
were sufficient for most capital requirements.

The reluctance of investors to accept limited liability seems to have been associated with the high rates of default, fraud, and other malfeasance of early limited companies. Supple (1977) argues that earlier, during the eighteenth century, many joint-stock companies had been small, indeed too small for diversification to motivate their incorporation, and that fraud had often been the intent of the entrepreneurs involved. Many were devoted to exploiting new inventions, where the potential for malfeasance was presumably great. $^{9}$

The poor performance of limited firms seems to have persisted in the later period, both in the public conception and in point of fact. Hannah (1976) notes that Parliamentary committee reports on liability legislation reflect public distrust in limited firms, and "even those who accepted ... its favourable effects on investment saw little future for the new companies.... Suppliers and customers, it was thought, would be reluctant to deal with them." (p. 20)

These expectations were largely borne out in the experience of limited firms in the generation following promulgation of the Joint-Stock Companies Act, as is demonstrated by the work of Shannon $(1932,1933)$. Of the 20,000 incorporations in the $1856-83$ period, approximately one-third never really began operation, a further 28 per cent were declared insolvent, 32 per cent voluntarily ceased operation, and 11 per cent "disappeared unnoticed." Life expectancy of the new entities was low. One-third failed in their first five years of operation; one-half within ten years, and only eight per cent were still extant in 1929. This record of failure was related to the reluctance of large firms to adopt limited liability. By the 1880s, less than 10 per cent of large-scale businesses had incorporated (Hannah, 1976; Forbes, 1986).

Contemporary accounts suggest that investors and policy-makers alike were concerned with the way liability rules affected the potential for malfeasance by stock promoters and the functioning of capital markets in general. To its opponents, liability reform would lead to fraud and undue speculation, according to Shannon (1931), and enterprise would function better if "kept within salutary bounds by dread of loss." (p. 374) The debates in Hansard in the period prior to 1856 indicated general concern that incorporation would undermine the reputation of British merchants with trading partners and general creditors. Such concerns, according to Shannon $(1932,1933)$, were largely borne out in the high failure rates and low life expectancy of the earliest limited companies. In general, "limited liability was no unmixed blessing [and] little deserves the panegyrics so often bestowed on it."

Jefferys (1948) studies the functioning of corporate capital markets of the period and finds that capital structure was typically designed to alleviate investors' concerns about the security and financial responsibility of limited companies. He suggests that the denomination of equity shares and the use of uncalled reserves of equity capital ${ }^{10}$ were used as signals of value and stability. One contemporary corporate finance "textbook," for

\footnotetext{
${ }^{9}$ These arguments echo the famous aphorism in The Wealth of Nations that, because of the separation of ownership and control, "negligence and profusion, therefore, must always prevail, more or less, in the management of the affairs of such a company." (p. 741)

${ }^{10}$ Company law of the period allowed investors to pay up only a fraction of the nominal value of the shares they owned. In effect, firms retained a put option on shareholders for the remaining equity.
} 
example, counselled entrepreneurs of limited firms that "probably no point ought to be more anxiously weighed than the nominal amount of shares into which the capital of the company is to be divided." ${ }^{11}$ A large share price was thought to limit the pool of potential investors to a small number of wealthy more likely to be informed about the prospects of the company and more able to exercise effective control of its behaviour. ${ }^{12}$ Similarly, the use of uncalled reserves of equity allowed corporate firms to mimic in part the allocation of risk associated with unlimited liability - and hence to replicate the incentives for moral hazard and monitoring as well.

\section{Limited liability, information, and investment}

Our review of historical literature studying the rise of limited companies in nineteenth century England suggests a number of observations. First, reform in company law, particularly through the Acts of 1844 and 1856, significantly reduced the costs to equity investors and entrepreneurs of obtaining limited liability. Prior to reforms, limited liability could only be obtained through special acts of Parliament. It is often suggested that this process was an expensive one for entrepreneurs, involving considerable effort and expenditure before legislation could be passed.

Second, English limited companies had had a long history of default-more particularly fraud and other malfeasance - which conditioned investors' expectations for the securities issued by later firms, and which fettered the development of capital markets before and after 1855. Indeed, Shannon's $(1932,1933)$ data on business failures in the 1856-83 period suggest that investors' cautious beliefs were particularly well-founded.

Third, many firms chose not to incorporate after the 1856 reforms, and relied instead on internal sources of finance, such as retained earnings from existing ventures and entrepreneurs' personal wealth. This slow rate of incorporation was particularly evident among, but not confined to, family-operated firms. In this regard, the experience of English companies appears to have differed from that of companies in Germany, the United States, and other countries, during the period. As Forbes (1986) notes, the reluctance to adopt limited liability in England is particularly striking, given that liability reform occurred later and industrial capital demands were higher there than in the United States. ${ }^{13}$ Moreover, incorporation tended to be undertaken by most firms in a small number of industries, but by few firms in other industries. Limited liability was obtained often by firms selling new products or adopting new processes, whereas firms in existing industries where capital demands were increasing commensurately (such as textile manufacturing) were less willing to incorporate.

Theoretical accounts of the role of limited liability have generally not addressed these stylized facts of the nineteenth century English experience. In general, an appropriate theoretical framework for understanding the development of the modern corporation has been absent. In this section, we develop a model of capital markets and liability rules.

\footnotetext{
${ }^{11}$ Loftus Fitz-Wygram, 1867, Limited Liability Made Practical, p. 7. Cited in Jefferys (1948).

${ }^{12}$ The chairman of the 1867 Commons Select Committee on Limited Liability asked rhetorically, "I suppose the lower you go in denomination the more ignorant people you catch?" Cited in Jefferys (1948), p. 349 .

${ }^{13}$ Between 1863 and 1890, the number of corporate firms in England grew by 400 per cent, compared to almost 1400 per cent in the United States during the same period (Forbes, 1986).
} 
As with the existing transaction-cost approach to the issue, costs of information play a crucial role in the model, as investors cannot verify ex ante the profitability of a venture. ${ }^{14}$ Again, as with the transaction-cost approach, creditors demand a risk premium for corporate (limited liability) debt, which just compensates them for the average rate of default on debt. ${ }^{15}$ Unlike in transaction-cost models, however, the equilibrium risk premium is appropriate only for the average firm. "Good" firms - with lower-than-average probability of default - therefore pay too much for limited liability debt, whereas "bad" firms - more likely than average to default - are subsidized in equilibrium. We show this leads to adverse selection in limited liability credit markets. Good firms choose unlimited liability if they have sufficient assets to back their securities, while bad firms choose limited liability status regardless of their balance sheets.

The possibility of adverse selection in limited liability credit markets leads to markedly different implications - for the efficiency of equilibrium and for the dynamic process of development in securities markets - than those described by the transaction-cost approach. With adverse selection, investors' beliefs about default rates among limited companies may be self-enforcing. Investors who believe that limited companies are more likely to default demand a higher risk premium for their debt. This higher cost of capital forces less risky, good firms out of limited liability capital markets, confirming investors' pessimistic beliefs.

In what follows, we develop an extremely simple model displaying these features. We demonstrate explicitly that the self-enforcing character of beliefs can lead to the existence of multiple equilibria in capital markets, and that equilibria are productively inefficient. We then investigate the effects of the costs of incorporation and the quantity of retained earnings on the nature of equilibrium.

\subsection{Incorporation and adverse selection in a credit market}

Entrepreneurs have access to a technology requiring an initial fixed capital outlay $K$, which produces a risky gross cash flow

$$
X= \begin{cases}A / p & \text { with probability } p \\ 0 & \text { with probability } 1-p\end{cases}
$$

The probability $p$ that the venture is successful is private information to the entrepreneur. Outside investors are uninformed about the project, and their common prior belief is that $p$ is uniformly distributed on the unit interval. The expected gross return to the project is $\bar{x}(p)=A$, independent of $p$. Thus all projects are equally profitable in expectation, but projects with lower $p$ are more risky.

The firm must issue securities to finance the initial capital cost $K$. Entrepreneurs have existing collateralizable assets $W$, which may consist of earnings retained as cash from previous ventures or of personal wealth. An entrepreneur's quantity of assets $W$ is a random variable independently and identically distributed among entrepreneurs with c.d.f. $F(w)$. For simplicity, $W$ is taken to be distributed independently of $p$, the riskiness of the entrepreneur's new venture.

\footnotetext{
${ }^{14} \mathrm{~A}$ project's cash flow can be observed costlessly ex post in the model, however. In this regard, the model departs from the "costly state verification" literature that underlies many previous studies of limited liability.

${ }^{15}$ This notion of rational expectations equilibrium is standard for models of this type.
} 
The firm may issue limited liability debt, or, if the entrepreneur has sufficient collateral, debt with unlimited liability may be issued. To issue limited liability debt, the firm must also pay a fixed $\operatorname{cost} B$, which represents the costs of incorporation.

A dollar invested in unlimited liability debt earns the exogenous risk-free gross rate of return $r$. To purchase limited liability debt, investors demand a risk-adjusted gross return $R$ if the project is successful. (There is no return to limited liability debt if the project fails.) Investors are risk neutral, so that the expected return to limited liability debt just equals the risk-free rate $r$ in equilibrium, or

$$
R=\frac{r}{\pi}
$$

where $\pi$ is the belief held by investors about the average probability of success $p$ of firms issuing limited liability debt.

It is assumed that $A-r(K+B)>0$, so that the expected return to the venture, net of capital and incorporation costs, is positive for all projects. If information were complete and symmetric, then, all projects would receive funding under limited liability at an appropriate risk-adjusted interest rate, regardless of the assets of the entrepreneurs. Because the market interest rate reflects only the average riskiness of limited liability debt, however, entrepreneurs with projects less risky than average may determine that limited liability debt is too costly, and opt out of corporate capital markets. It is this problem of adverse selection that we study here.

Entrepreneurs are risk neutral, ${ }^{16}$ so that the value of the venture, when funded wholly through limited liability debt, is

$$
\begin{aligned}
V^{L}(p, \pi) & =A-p R(K+B) \\
& =A-\frac{p}{\pi} r(K+B)
\end{aligned}
$$

given that investors believe the average quality of limited companies is $\pi$. If sufficient collateral is available and unlimited liability is chosen, the value of the venture is

$$
V^{U}(p)=A-r K
$$

for all $p$. It follows that an entrepreneur chooses to issue unlimited liability securities if $W \geq K$, so that sufficient collateral is available, and $V^{U}(p)>V^{L}(p, \pi)$, given investors' beliefs $\pi$, or equivalently if

$$
p>\hat{p}(\pi)=\frac{\pi}{1+B / K}
$$

(Note that $V^{U}(p)>0$ by assumption, so that unlimited liability is always preferred to foregoing the project.)

\footnotetext{
${ }^{16} \mathrm{~A}$ more general analysis would consider risk averse entrepreneurs who sell equity claims on their ventures in order to improve risk sharing. While we introduce an equity market to the analysis, the implications of risk aversion will not be explored. This would considerably complicate the model without changing essential features.
} 
Conversely, the entrepreneur prefers limited liability debt if $V^{L}(p, \pi) \geq V^{U}(p)$, which holds if and only if $p \leq \hat{p}$. Finally, a cash-constrained entrepreneur (with $W<K$ ) offers limited liability debt if $V^{L}(p, \pi) \geq 0$, or, after rearranging,

$$
p \leq \pi \frac{A}{r(K+B)} .
$$

Define

$$
\tilde{p}(\pi)=\min \left\{\pi \frac{A}{r(K+B)}, 1\right\}
$$

as the expected excess rate of return to creditors of limited liability firms. Observe that $\tilde{p}<1$ if and only if $\pi<\theta=r(K+B) / A$, and that $\theta<1$ since $A-r(K+B)>0$ by assumption. Hence there exist some admissible beliefs $\pi$ for which the least risky projects are not undertaken when entrepreneurs are cash-constrained; for other possible beliefs, these projects are undertaken with limited liability for entrepreneurs.

In summary, the average quality of ventures financed with limited liability depends on the beliefs of outside investors, through their effect on the "hurdle rates" $\hat{p}$ and $\tilde{p}$. Entrepreneurs of type $p \leq \hat{p}$ choose limited liability regardless of their assets $W$, using the higher quality of other limited firms to obtain credit at a subsidized rate of interest. Entrepreneurs of type $p>\hat{p}$, being less prone to failure, would prefer to issue debt in the unlimited liability market, where problems of adverse selection do not occur. If their assets $W$ are less than capital requirements $K$, however, they are unable to do so. Such cash-constrained entrepreneurs of type $p \in(\hat{p}, \tilde{p}]$ then choose to issue limited liability debt. Cash-constrained entrepreneurs with $p>\tilde{p}$, whose probability of successfully repaying the loan is highest, find the cost of limited liability debt so unattractive that they choose not to invest at all.

Somewhat more formally, an optimal decision rule for entrepreneurs given market beliefs $\pi$ is to issue limited liability debt and undertake the project if and only if $p \leq \hat{p}(\pi)$ or $p \leq \tilde{p}(\pi)$ and $W<K$, and to issue unlimited liability debt if and only if $p \in(\hat{p}(\pi), \tilde{p}(\pi)]$ and $W \geq K$.

But the critical values $\hat{p}$ and $\tilde{p}$ depend on the market rate of interest for limited liability debt, which depends in turn on uninformed creditors' belief $\pi$ about the riskiness of the average limited company. We seek to characterize rational-expectations equilibria, in which creditors' ex ante beliefs about default rates are consistent with the actual performance of firms on average. To this end, define $f(\pi)$ as the average default probability $p$ of entrepreneurs choosing limited liability. By Bayes' rule,

$$
\begin{aligned}
f(\pi)= & E(p \mid p \leq \hat{p}) \operatorname{Prob}(p \leq \hat{p}) \\
& +E(p \mid \hat{p}<p \leq \tilde{p}) \operatorname{Prob}(\hat{p}<p \leq \tilde{p}) \operatorname{Prob}(W<K) \\
= & \frac{1}{2}\left[\phi \tilde{p}^{2}+(1-\phi) \hat{p}^{2}\right],
\end{aligned}
$$

where $\phi=F(K)$ is the probability an entrepreneur has insufficient collateral to issue unlimited liability securities. 
A rational expectations equilibrium is therefore completely specified by the optimal decision rule for entrepreneurs derived above and a belief $\pi^{*}$ for uninformed creditors such that

$$
\pi^{*}=f\left(\pi^{*}\right) .
$$

We will proceed to characterize such equilibria.

There are two cases for consideration, which depend on the two components in the definition of $\tilde{p}$. First, if $\pi<\theta$, so that $\tilde{p}(\pi)<1$, then the average risk of limited companies, say $f_{1}(\pi)$, is

$$
f_{1}(\pi)=\frac{1}{2}\left[\phi\left(\frac{A}{r(K+B)}\right)^{2}+(1-\phi) \alpha^{2}\right] \pi^{2},
$$

where $\alpha=K /(K+B)$ is the ratio of capital demands from entrepreneurs in the unlimited and limited sectors. Second, if $\pi \geq \theta$, so that $\tilde{p}(\pi)=1$, then the average risk of limited companies, say $f_{2}(\pi)$, is

$$
f_{2}(\pi)=\frac{1}{2}\left[\phi+(1-\phi) \alpha^{2} \pi^{2}\right]
$$

In these two cases, creditors' beliefs about risk affect actual risk in qualitatively different ways. Consider first the effects of an increase in $\pi$ given $\pi<\theta$. This reduces the cost of limited liability debt, inducing some unconstrained entrepreneurs to switch from unlimited to limited liability as $\hat{p}$ rises. Moreover, some cash-constrained entrepreneurs who had not undertaken the project, due to the high cost of limited liability debt, are likewise induced to issue limited liability debt as $\tilde{p}$ rises. Both these considerations lead the average quality of limited companies to rise in response to the rise in beliefs $\pi$. When $\pi \geq \theta$ so that $\tilde{p}=1$, in contrast, the latter effect is absent. The least risky projects (those with $p$ close to one) are being undertaken, and further increases in $\pi$ can only raise average quality of limited companies by inducing a switch by unconstrained entrepreneurs from unlimited to limited liability.

In both cases, however, an increase in expected quality $\pi$ does indeed raise actual quality $f(\pi)$. That is,

$$
\frac{\partial f(\pi)}{\partial \pi}= \begin{cases}{\left[\phi\left(\frac{A}{r(K+B)}\right)^{2}+(1-\phi) \alpha^{2}\right] \pi>0} & \text { if } \pi<\theta \\ (1-\phi) \alpha^{2} \pi>0 & \text { if } \pi>\theta .\end{cases}
$$

It is in this sense that investors' beliefs are potentially self-enforcing. Moreover, this complementarity in beliefs may be an equilibrium phenomenon, in the sense that there exist multiple equilibrium beliefs $\pi^{*}$ such that $\pi^{*}=f\left(\pi^{*}\right)$.

It will be demonstrated that, in some cases, there exist three rational expectations equilibria in limited liability credit markets. To show this, note that $f_{1}(0)=0$ and $\theta>0$, so that $\pi_{1}^{*}=0$ is a rational expectations equilibrium. In words, when creditors believe average quality of limited companies to be very low, they charge prohibitively high interest rates, inducing all but the riskiest entrepreneurs to adopt unlimited liability or forego the investment. Hence beliefs are confirmed in equilibrium. 
Note from (8), moreover, that $\partial f_{2} / \partial \pi<1$ for all $\pi>\theta$. Hence $f(\theta)<\theta$ implies $f(\pi)<\pi$ for all $\pi \geq \theta$. It follows that if $f(\theta)<\theta, \pi_{1}^{*}=0$ is the unique rational expectations equilibrium. In this case, the corporate credit market is effectively closed in equilibrium. (This case is presumably of little interest, and so in what follows we focus largely on the case in which some entrepreneurs are willing to incorporate in equilibrium.)

Conversely, suppose that $f(\theta)>\theta .{ }^{17}$ Then there also exists an equilibrium in which a sufficiently large number of high-quality projects - those operated by cash-constrained entrepreneurs - are financed with limited liability debt. These projects support more optimistic beliefs about average project quality, resulting in a lower market interest rate. This leads in turn to the issue of limited liability debt by relatively high-quality entrepreneurs who are not cash-constrained, which supports the initial optimistic beliefs of investors.

To verify this, observe that $f$ is continuous on $[0,1]$. Since $f(\theta)>\theta$ by assumption and since $f(1)<1 / 2$ by $(7)$, it follows there exists some $\pi_{2}^{*} \in(\theta, 1)$ such that $f\left(\pi_{2}^{*}\right)=\pi_{2}^{*}$. Indeed, it is possible to solve for $\pi_{2}^{*}$ explicitly. From (7),

$$
\alpha^{2}(1-\phi)\left(\pi_{2}^{*}\right)^{2}-2 \pi_{2}^{*}+\phi=0
$$

so that

$$
\pi_{2}^{*}=\frac{1}{\alpha^{2}(1-\phi)}\left[1-\sqrt{1-\alpha^{2} \phi(1-\phi)}\right] .
$$

These arguments are depicted in Figure 1. Note that continuity implies the existence of a third equilibrium belief $\pi_{3}^{*} \in(0, \theta)$. This equilibrium is unstable under naive Marshallian dynamics, however, whereas the other two are stable. Hence we concentrate on the latter two equilibria.

Within this highly stylized model of the economy, these equilibria can be ranked by the potential Pareto criterion. In the "high" equilibrium, all entrepreneurs' ventures are funded, but cash-constrained entrepreneurs operating good (low-risk) projects are forced to subsidize high-risk projects in order to obtain funding in limited liability debt markets. In the "bad" equilibrium, extreme adverse selection occurs, as only the very highest-risk projects are funded with limited liability, and all other cash-constrained entrepreneurs choose not to undertake investments. Thus the aggregate level of investment is lower in the latter equilibrium. In both equilibria, however, aggregate investment is lower than in the first-best allocation, in which all projects obtain funding.

Having characterized equilibrium for the model, we turn to the central question of the comparative static changes in equilibrium in response to changes in parameter values. In particular, how does an exogenous change in the cost of incorporation $B$, such as that induced by liability reform, affect equilibrium beliefs about the quality of limited companies and therefore the equilibrium cost of capital for limited companies? Similarly, how does an exogenous change in the initial assets or retained earnings of entrepreneursresulting in a change in the parameter $\phi$-affect the equilibrium cost of capital for limited companies? Since $f$ is continuous in $\pi$, it follows that a sufficient condition for the "high"

\footnotetext{
${ }^{17}$ This condition holds given that physical capital costs $K$ are small relative to gross returns $A$ and incorporation costs $B$, and that a sufficiently large fraction of entrepreneurs are cash-constrained, so that $\phi$ is sufficiently large.
} 


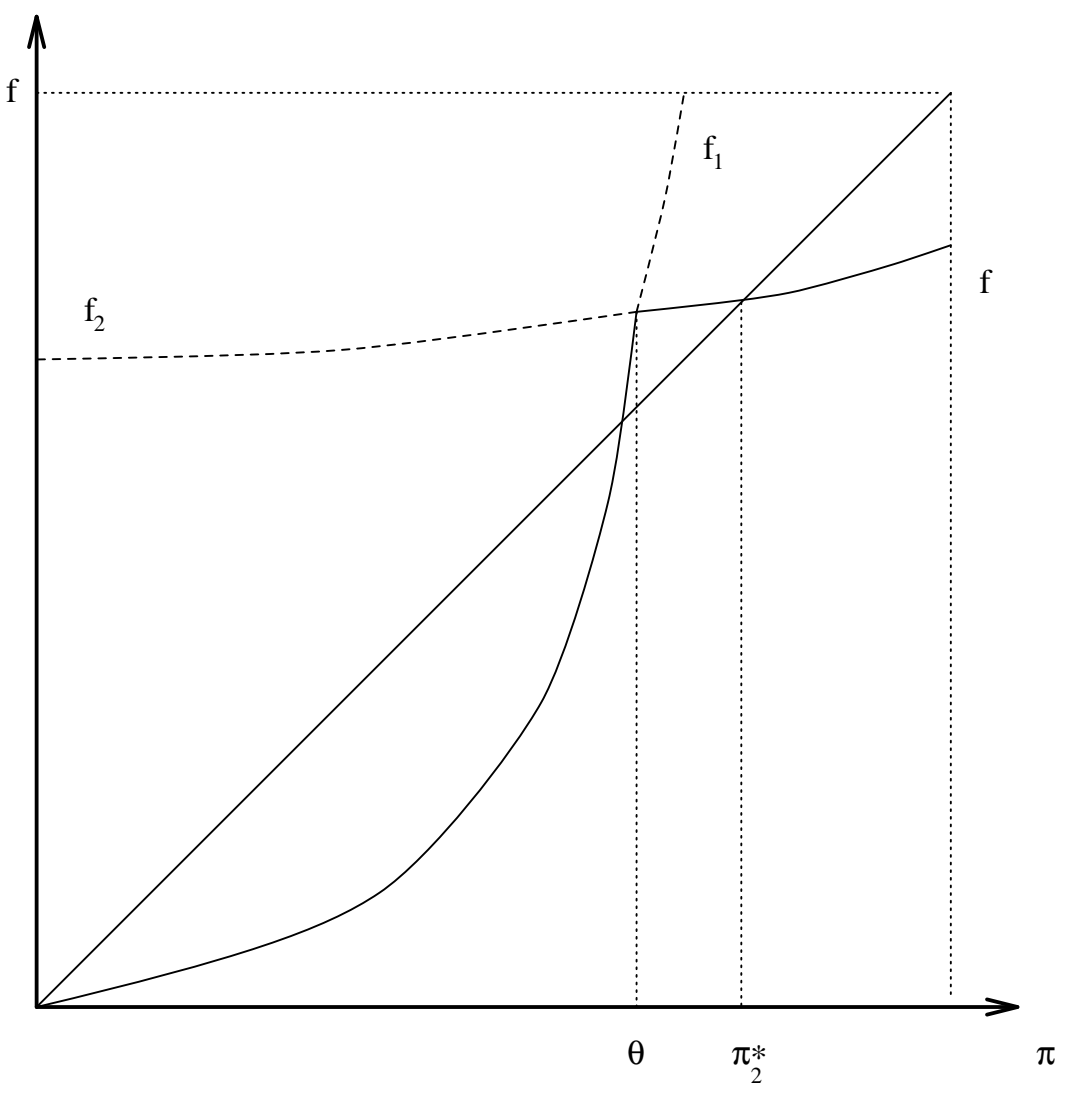

Figure 1: Multiple equilibria in the limited liability debt market

equilibrium $\pi_{2}^{*}$ to be increasing in a parameter is that $f$ be globally increasing in the parameter. ${ }^{18}$ (The "low" equilibrium $\pi_{1}^{*}=0$ is independent of parameter values.)

The logic of comparative statics results is straightforward. Increases in the cost of incorporation $B$ reduce the average loan quality for any investor beliefs $\pi$, and hence must reduce equilibrium loan quality. To see this, differentiate $(6)-(7)$ with respect to $B$ and obtain

$$
\frac{\partial f(\pi)}{\partial B}= \begin{cases}-(K+B)^{-1}\left[\phi(A / r(K+B))^{2}+(1-\phi) \alpha^{2}\right] \pi^{2} \leq 0 & \text { if } \pi \leq \theta \\ -(K+B)^{-1}(1-\phi) \alpha^{2} \pi^{2}<0 & \text { if } \pi>\theta\end{cases}
$$

This comparative static property is depicted in the first panel of Figure 2. Locally, small reductions in the cost of incorporation lead more firms to incorporate, attenuating adverse selection and reducing the cost of capital for limited companies. But the result also applies for non-infinitesimal changes. Consider an initial environment in which $B$ is sufficiently large that the unique equilibrium is $\pi_{1}^{*}=0$. Given a sufficiently large

\footnotetext{
${ }^{18}$ Here we follow the approach to equilibrium comparative statics of Milgrom and Roberts (1994). Alternatively, comparative static derivatives could be obtained explicitly by differentiating (9). The approach adopted here has the advantage of demonstrating the robustness of comparative static effects to relaxation of our simplifying assumptions.
} 

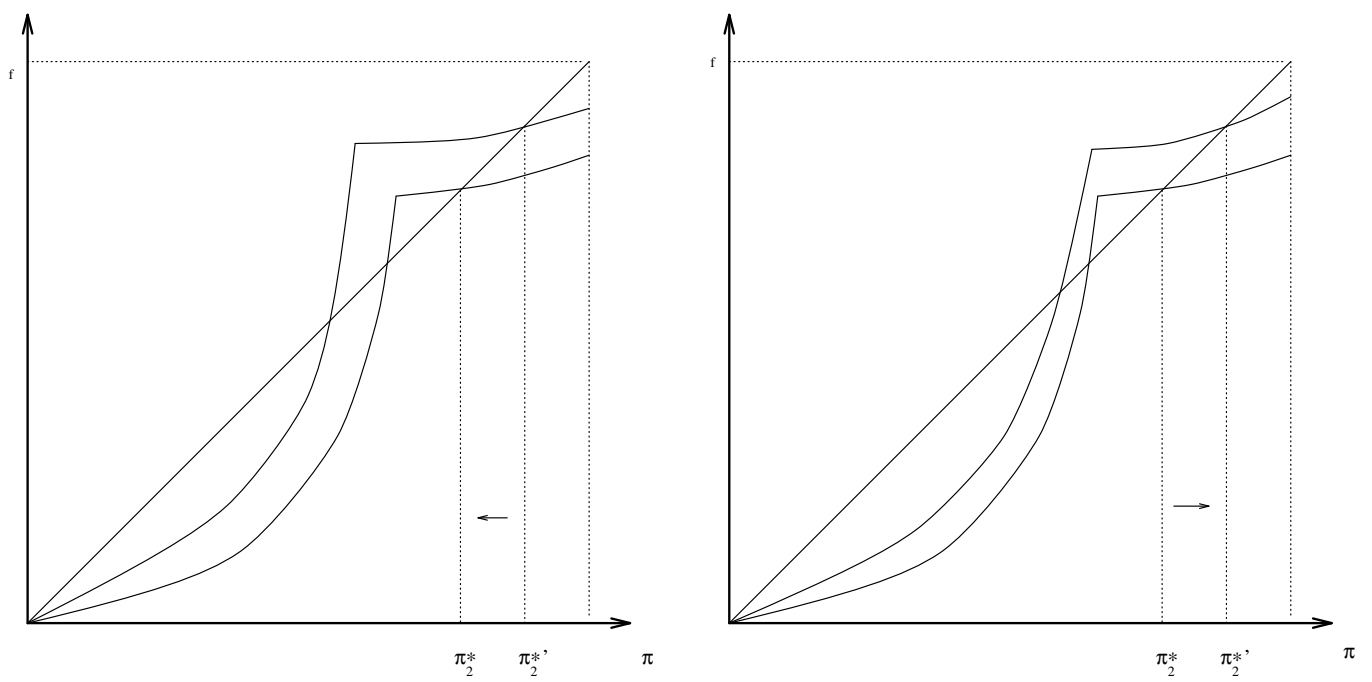

Figure 2: Effects of an increase in incorporation costs (left) and a decrease in assets (right)

reduction in $B, \pi_{1}^{*}$ remains an equilibrium, but a new, more efficient equilibrium exists at $\pi_{2}^{*}>0$. (As the evidence discussed in Section 3 suggests, this situation may well describe the changes engendered by the 1856 reforms in Great Britain.) In this case, a shift to the new equilibrium requires a discrete jump in investors' beliefs and in the behaviour of entrepreneurs. Issues of the dynamics of coordination and equilibrium selection are largely outside the scope of this paper. We note only that the existence of $\pi_{1}^{*}$ as a selfenforcing belief makes it difficult, in the short run at least, for capital market participants to coordinate beliefs on the new and productively efficient equilibrium. This is particularly true when tradition and past experience condition investors to believe that default rates are prohibitively high for limited companies. Thus the model provides an alternative explanation for the performance of English capital markets in the generation following the liability reforms, in which creditors were reluctant to deal with limited companies, and hence existing firms were unwilling to incorporate.

A similar analysis applies to increases in the degree of cash constraints experienced by entrepreneurs which raise $\phi$ yield increases in average loan quality for all $\pi$ and hence increases in equilibrium loan quality as well. Differentiating (6)-(7) with respect to $\phi$,

$$
\frac{\partial f(\pi)}{\partial \phi}= \begin{cases}\frac{1}{2} \alpha^{2} \pi^{2}\left((A / r K)^{2}-1\right) \geq 0 & \text { if } \pi \leq \theta, \\ \frac{1}{2}\left(1-\alpha^{2} \pi^{2}\right)>0 & \text { if } \pi>\theta .\end{cases}
$$

The comparative static results are depicted in the second panel of Figure 2. An increase in the fraction of entrepreneurs with sufficient collateralizable assets (viz. a decrease in $\phi$ ) raises the default rate for limited companies, as more low-risk entrepreneurs choose not to incorporate. In extreme cases, if $\phi$ is sufficiently small, the high-investment equilibrium $\pi_{2}^{*}$ ceases to exist, as there are too few cash-constrained entreprenurs to maintain the optimistic beliefs of creditors. These observations offer a new perspective on the decline in productivity and slower growth rate experienced in Britain during the "second Industrial 
Revolution" of the latter half of the nineteenth century. ${ }^{19}$ It is frequently argued that Britain's early success was, paradoxically, responsible for its later failures, as firms with large stocks of old capital that they were unwilling to scrap when technological innovations were introduced. The explanation suggested here is similar but does not rely on the vintage of the stock of physical capital. Instead, the larger stock of financial capital in successful firms decreases their reliance on external capital markets. This leads to a greater degree of adverse selection, as more low-risk but cash-constrained firms are unable to invest.

\subsection{The role of equity markets}

The previous section studied equilibrium in limited and unlimited liability credit markets and demonstrated that cash-constrained entrepreneurs might be rationed from capital markets as a consequence of adverse selection. But this account ignores the possible role of equity markets in alleviating adverse selection and leading to efficient investment allocations.

If entrepreneurs with insufficient wealth to secure unlimited liability debts have the opportunity to issue equity shares in their ventures, then cash constraints need not be binding on such entrepreneurs. In principle, then, firms could potentially avoid problems of mispriced debt by selling shares in the venture and using the proceeds to guarantee unlimited liability debt.

But such a strategy need not be desirable for entrepreneurs with low-risk ventures, as long as investors' beliefs can lead the firm's equities to be mispriced as well. Since shareholders in a firm with unlimited liabilities must incur additional transaction costs to monitor other shareholders and guard against the possibility of default - as argued by Halpern et al. (1980), Carr and Mathewson (1988), and others - an equity offering of an unlimited liability firm will, all else equal, be priced lower than the offering of a limited corporation. The value of high-return, low-risk projects to the entrepreneur will be diluted by the additional transaction costs; hence incorporation may be attractive to such firms, even though they regard limited liability debt to be underpriced. In equilibrium, better entrepreneurs compare the dissipation of rents resulting from underpriced debt to that resulting from underpriced equity, and choose liability status accordingly. Thus the liability status of firms - and, accordingly, the aggregate level of transaction costs associated with securities markets - is dependent on the equilibrium beliefs of investors, which are themselves endogenous to the decision rules employed by entrepreneurs.

In this section, we sketch a simple model with these features and explore some of its implications.

Consider an entrepreneur with an opportunity to undertake an investment project which generates a risky cash flow $x$ in the next period, where $x$ is normally distributed with mean $\mu$ and variance $\sigma^{2}$. The standard deviation of returns $\sigma$ is known to the entrepreneur but not to potential outside investors, whereas $\mu$ is identical for all projects and common knowledge to entrepreneurs and investors. Outsiders share a common prior belief that $\sigma$ is a random variable with support $[\underline{\sigma}, \bar{\sigma}]$ and c.d.f. $G(\sigma)$. The venture requires

\footnotetext{
${ }^{19}$ The very existence of this phenomenon is the subject of much debate. But productivity growth rates did indeed decline late in the century, and industrialization did proceed at a faster pace in the United States and Germany. See, e.g., Pollard (1994) for a discussion.
} 
an initial capital investment $K$, to be financed through an issue of equity shares in the firm. In addition, the firm requires working capital $D$ in the form of debt or trade credits. (Thus, for simplicity, we take the firm's leverage decision as exogenous, in order to focus on choice of liability rule. ${ }^{20}$ ) The entrepreneur is risk neutral and seeks to maximize expected returns to the project, net of interest costs and equity dilution. By assumption, the net present value of all projects is positive.

If the firm adopts unlimited liability, its debt is free of default risk and pays the exogenous risk-free interest rate, which is taken to be unity for simplicity. In this case, outside equity is required to finance the initial capital outlay $K$ and to provide a guarantee for unlimited liability debt. Let $\alpha^{U}$ be the fraction of the firm the entrepreneur must sell to finance the investment. The expected returns to the entrepreneur are

$$
V^{U}=\left(1-\alpha^{U}\right)(\mu-D) \quad(\text { all } \sigma) .
$$

If the firm incorporates and adopts limited liability, in contrast, its debt carries non-zero risk of default, and it must accordingly pay a risk-adjusted nominal interest rate greater than unity. Let the face value of limited liability debt with ex ante market value $D$ be $F>D$. Let $\alpha^{L}$ be the fraction of the firm sold to creditors in exchange for an initial equity investment $K$. Then expected returns to the entrepreneur under limited liability are

$$
V^{L}(\sigma, F)=\left(1-\alpha^{L}\right) E(\max \{x-F, 0\})
$$

Define $z=(\mu-F) / \sigma$. Since $x$ is normally distributed, it follows that

$$
\begin{aligned}
V^{L}(\sigma, F) & =\left(1-\alpha^{L}\right)[(1-\Phi(-z))(\mu-R D)+\sigma \phi(-z)] \\
& =\left(1-\alpha^{L}\right) \sigma(\Phi(z) z+\phi(z))
\end{aligned}
$$

where $\Phi$ and $\phi$ are the standard normal distribution and density, respectively.

An entrepreneur of type $\sigma$ therefore chooses optimally to undertake the investment with limited liability if and only if $V^{L}(\sigma) \geq V^{U}$, given the market price of limited liability debt, and chooses unlimited liability otherwise. (It is assumed that it is always preferable to invest under one liability rule or the other than to forego the investment entirely.) The entrepreneur's residual claim on the firm with risky debt represents a call option on a fraction $\left(1-\alpha^{L}\right)$ with exercise price $F$, and the value of the option is increasing in the variance of cash flows, since differentiation of (12) yields

$$
\frac{\partial V^{L}(\sigma, F)}{\partial \sigma}=\left(1-\alpha^{L}\right) \phi(z)>0 \text {. }
$$

It follows that, for all $F \geq D$, there exists a critical project risk $\hat{\sigma} \in[\underline{\sigma}, \bar{\sigma}]$ such that $V^{L}(\sigma, F) \geq V^{U}$ if and only if $\sigma \geq \hat{\sigma}$. That is, any risk premium demanded for limited liability debt leads to an adverse selection of firms that choose to adopt limited liability.

\footnotetext{
${ }^{20}$ This assumption appears consistent with the nature of British securities markets in the period under study. Debentures markets and bank lending were largely non-existent, and firms relied on suppliers and customers for the trade credits necessary to finance transactions.
} 
This optimal decision rule depends on the equilibrium prices of the securities, and hence on the beliefs of outside investors about $\sigma$, conditional on the entrepreneur's liability choice. We turn next to the issue of equilibrium in securities markets.

Suppose investors believe that an entrepreneur of type $\sigma$ adopts limited liability if and only if $\sigma \geq \hat{\sigma} \in[\underline{\sigma}, \bar{\sigma}]$. If the market for limited liability debt is to be free from arbitrage opportunities, then creditors expect to break even on debt offered by 6 the pool of limited firms, so that $E(\min \{x, F\} \mid \sigma \geq \hat{\sigma})=D$, or using the normality of $x, F(\hat{\sigma})$ is implicitly defined by

$$
[1-G(\hat{\sigma})]^{-1} \int_{\hat{\sigma}}^{\bar{\sigma}}(\mu-\sigma(\Phi(z) z+\phi(z))) d G(\sigma)=D
$$

The integrand in (13) represents the expected return to risky debt issued by a firm of type $\sigma$, say $V^{D}(\sigma)$. Since $V^{D}(\sigma)>0$ and

$$
\frac{\partial V^{D}(\sigma)}{\partial \sigma}=\Phi(z)>0
$$

implicit differentiation of (13) indicates that $F$ is increasing in $\hat{\sigma}$. Not surprisingly, then, an increase in subjective risk of limited liability debt leads to a higher equilibrium risk premium for the debt issued by all limited firms.

In the market for shares of limited firms, investors pay $K$ for a fraction $\alpha^{L}$ of the firm. The anticipated cash flows to the project, net of expected debt costs, are

$$
\tilde{V}^{L}=\mu-D,
$$

where we have used the debt-market equilibrium condition. A shareholder investing one dollar in the firm foregoes the risk-free return in doing so; hence, the absence of arbitrage opportunities in equilibrium implies $\alpha^{L} \tilde{V}^{L}=K$, or

$$
\alpha^{L}=\frac{K}{\mu-D} .
$$

The situation in the equity market for unlimited firms is similar, except that there investors incur additional deadweight costs of monitoring fellow shareholders to ensure their personal solvency in the event of a default by the firm. In general such costs depend on the number of shareholders in the firm and the anticipated probability of default. Here, for simplicity, aggregate transaction costs are taken to be some exogenous constant monetary cost $C$. Investors therefore demand a larger share of the unlimited firm in compensation, and $\alpha^{U} \tilde{V}^{U}=K+C$, or

$$
\alpha^{U}=\frac{K+C}{\mu-D}
$$

Substituting (15) into (10) implies

$$
V^{U}=\mu-(D+K+C) .
$$

A deterministic rational expectations equilibrium of the model is defined as a belief $\hat{\sigma}^{*}$ for uninformed investors such that: (i) security markets clear, so that (13)-(15) hold 
given beliefs; (ii) entrepreneurs choose incorporation optimally, so that limited liability is chosen by an entrepreneur of type $\sigma$ if and only if $V^{L}(\sigma, F) \geq V^{U}$, given equilibrium securities prices; and (iii) beliefs of uninformed investors are consistent with the optimal incorporation rule, so that $V^{L}(\sigma, F) \geq V^{U}$ if and only if $\sigma \geq \hat{\sigma}^{*}{ }^{21}$ To establish the existence of at least one such equilibrium, define $f(\hat{\sigma})=\min \left\{\sigma \in[\underline{\sigma}, \bar{\sigma}]: V^{L}(\sigma, F(\hat{\sigma})) \geq\right.$ $\left.V^{U}\right\}$. Thus when investors believe that entrepreneurs of type $\sigma \geq \hat{\sigma}$ adopt limited liability, and risky debt is priced accordingly, then it is optimal for entrepreneurs of type $\sigma \geq f(\hat{\sigma})$ to choose limited liability. A rational expectations equilibrium is then a belief $\sigma^{*}$ such that $f\left(\sigma^{*}\right)=\sigma^{*}$. Since, by construction, $f$ maps $[\underline{\sigma}, \bar{\sigma}]$ continuously into itself, at least one fixed point of $f$ exists. Equilibria are non-trivial, moreover, in the sense that at least some firms adopt limited liability. To see this, suppose that investors believe that all but the riskiest firms adopt unlimited liability, so that $\hat{\sigma}=\bar{\sigma}$. Then $V^{L}(\bar{\sigma}, F(\bar{\sigma}))=\mu-D-K>V^{U}$, so that $f(\bar{\sigma})<\bar{\sigma}$. Obversely, an equilibrium in which all firms adopt limited liability may exist, or all equilibria may entail positive probability that firms choose both liability rules, depending on parameter values. Let $\bar{F}=F(E \sigma)$ be the equilibrium price of limited debt when creditors believe all firms adopt limited liability. Since $V^{L}$ is increasing in $\sigma$, this belief is confirmed in equilibrium if and only if $V^{L}(\underline{\sigma}, \bar{F}) \geq V^{U}$, or (rearranging (12)) if transaction costs $C$ associated with unlimited liability are sufficiently large relative to the value of the firm.

As in the model of credit markets in Section 4.1, the potentially self-fulfilling nature of investors' beliefs can lead to multiple equilibria in debt and equity markets. Although explicit solutions of examples generating multiple equilibria are intractable in this case, note that

$$
\frac{\partial f}{\partial \hat{\sigma}}=\lambda\left(\frac{\mu-F}{\hat{\sigma}}\right) \frac{\partial F(\hat{\sigma})}{\partial \hat{\sigma}}>0,
$$

where $\lambda(z)=\phi(z) / \Phi(z)$ is the hazard rate of the marginal firm, evaluated at its break-even cash flow. Hence actual risk of limited debt, given the selection process, is an increasing function of perceived risk $\hat{\sigma}$.

\section{English companies and the incorporation decision}

The model developed in the preceding section suggests that reforms in liability legislation may lead to adverse selection in the incorporation decisions of firms. In this section, we examine the experience of the earliest firms to incorporate following the 1856 reforms in Great Britain.

The Act of 1856 represents a unique opportunity for the researcher interested in business organization and capital markets, inasmuch as it introduced not only general limited liability but also the beginnings of modern reporting requirements for British companies. ${ }^{22}$ Passage of the Act constitutes a particularly interesting natural experiment in the effects of liability regimes, in that it allows study of the incorporation decisions of a group of firms, at a single point in time, in response to a significant change in regulatory environment.

\footnotetext{
${ }^{21}$ With slightly more formality, this could be construed as a definition of the pure-strategy sequential equilibria of a fairly standard signalling game.

${ }^{22}$ Joint-stock companies, defined as those with seven or more outside investors, were required under the Act to register, stating whether they were adopting limited liability or not, and thereafter to make annual returns reporting on the operation of the company and its finances.
} 
Table 1: Failure rates, by industry and liability status

\begin{tabular}{lcccc} 
Industry & \multicolumn{2}{c}{$\begin{array}{c}\text { Unlimited } \\
\text { companies }\end{array}$} & \multicolumn{2}{c}{$\begin{array}{c}\text { Limited } \\
\text { companies }\end{array}$} \\
\hline Mining \& smelting & 0.62 & $(16)$ & 0.48 & $(27)$ \\
Manufacturing & 0.32 & $(25)$ & 0.50 & $(28)$ \\
Utilities \& transport & 0.06 & $(174)$ & 0.07 & $(86)$ \\
Trade \& commerce & 0.04 & $(56)$ & 0.29 & $(17)$ \\
Finance & 0.25 & $(12)$ & 0.25 & $(4)$ \\
Construction \& real estate & 0.11 & $(27)$ & 0.30 & $(10)$ \\
All industries & 0.12 & $(310)$ & 0.24 & $(172)$ \\
\hline
\end{tabular}

Note: Cell sizes in parentheses.

The data for the study are derived from an 1864 report by the Registrar of Companies to Parliament, ${ }^{23}$ which records the names, industries, places of business and basic financial structure information of the 4193 corporations registered under the Act between 1856 and 1864. In the analysis, we focus on the subsample of English companies which were in existence at the time of passage of the Act and which had registered prior to $1861 .{ }^{24,25}$

These firms had previously registered under the Registration Act of 1844 (perforce with unlimited liability) and were required to register again, claiming limited or unlimited liability. In the sample, approximately two-thirds of firms chose unlimited liability, whereas one-third chose limited liability. The essential question the analysis seeks to answer is then, what determined the incorporation decisions of these firms? To what extent did it reflect expectations of future performance of the company, and therefore lead to problems of adverse selection in capital markets?

Financial performance measures are difficult to obtain for the period under study. Accounting profit statements were not generally published, and stock return series are difficult to construct, as markets were thin and shares traded infrequently. ${ }^{26}$ The Registrar's report does, however, record which of the companies had ceased operations by 1864 . While this is certainly an imperfect indicator of financial performance, it is arguably the best measure of entrepreneurs' ex ante beliefs about default probability, since such private information seems likely to be short-term in nature.

Table 1 records the failure rates of firms in the sample by broad industry category and by chosen liability status. The table indicates that 24 per cent of limited firms and 12 per cent of unlimited firms had failed by $1864 .{ }^{27}$ Failure rates were higher for limited firms in four of the six industries. The higher failure rate is especially pronounced for firms in the

\footnotetext{
${ }^{23}$ Return of Names, Places of Business, Date of Registration, Nominal Capital, and Number of Shares of Joint Stock Companies, 1864 (452) LVIII.291. Henceforth called the Registrar's report.

${ }^{24}$ The companies registering after 1861 were mostly insurance firms, which had previously been covered by separate legislation and whose liability decisions may have been governed by other regulatory considerations.

${ }^{25}$ We further restricted the sample under study as follows. Observations with missing data and those "registered in error" were excluded. This eliminated 78 observations. In addition, nine observations with nominal capital greater than $£ 400$ thousand were deleted because they appeared to be influential in estimation procedures. These firms' capital was more than five standard deviations above the mean.

${ }^{26}$ Shilts (1992) notes that current share prices are available for only eight of the firms in the sample.

${ }^{27}$ These figures are roughly similar to those reported for all firms in the period by Shannon (1932).
} 
Table 2: Probit estimates of failure, probability derivatives

\begin{tabular}{|c|c|c|c|}
\hline Independent variable & (1) & (2) & $(3)$ \\
\hline CAPITAL & - & $0 \cdot 12^{\dagger}$ & $0 \cdot 10^{\dagger}$ \\
\hline CAPITAL $^{2}$ & - & $-0 \cdot 04^{\dagger}$ & $-0 \cdot 04^{\dagger}$ \\
\hline DENOM & - & $-0 \cdot 01$ & $-0 \cdot 02$ \\
\hline SHRHLDR & - & $0 \cdot 00$ & $0 \cdot 01$ \\
\hline DNEW & - & - & $0 \cdot 15^{*}$ \\
\hline \multicolumn{4}{|c|}{ Limited liability dummies: } \\
\hline Mining \& smelting & -0.06 & $-0 \cdot 07$ & $-0 \cdot 09$ \\
\hline Manufacturing & $0 \cdot 12^{*}$ & $0 \cdot 11^{*}$ & $0 \cdot 03$ \\
\hline Utilities \& transport & $0 \cdot 01$ & $0 \cdot 01$ & $-0 \cdot 02$ \\
\hline Trade \& commerce & $0 \cdot 41^{* *}$ & $0 \cdot 41^{* *}$ & $0 \cdot 30^{*}$ \\
\hline Finance & $0 \cdot 00$ & $-0 \cdot 02$ & $-0 \cdot 06$ \\
\hline Constr. \& real estate & $0 \cdot 19^{*}$ & $0 \cdot 15^{\dagger}$ & $0 \cdot 10$ \\
\hline Number of observations & 482 & & \\
\hline \multicolumn{4}{|c|}{$\begin{array}{l}\text { Notes: Calculated at means of independent vari- } \\
\text { ables. Estimates for dummy variables are for dis- } \\
\text { crete change from zero to one. } \\
\dagger \text { Significant at } 20 \text { per cent level. } \\
\text { * Significant at } 10 \text { per cent level. } \\
\text { ** Significant at } 5 \text { per cent level. }\end{array}$} \\
\hline
\end{tabular}

Trade and commerce category; this industry includes many firms which operated abroad, for which problems of asymmetric information may have been greater. Thus the data are broadly indicative of the notion that firms choosing limited liability were more likely to fail, and that adverse selection may have occurred.

The liability decision may of course be influenced by factors other than entrepreneurs' private beliefs about default probability. Table 2 presents probit estimated probability derivatives of a reduced-form model relating the failure of firms in the sample to industry, liability status, and the other variables in the data set. Column 1 of the table reports results from the estimation procedure when only interacted dummy variables for industry and liability status are included. (For the sake of brevity, industry dummy variables are excluded from reported results in all columns.) Estimates in column 2 also include the firm-specific financial variables, and estimates in column 3 also include a dummy variable for the youngest firms in the sample.

Estimates in column 1, which include only the industry-liability dummies, confirm the results reported in Table 1 for differences in mean failure rates. In three of the industries, based on the fitted probability differences, it is possible to reject at any reasonable level of significance the hypothesis that failure probability is greater for limited liability firms. The hypothesis is not rejected at the ten per cent level in two of the industries, Manufacturing and Construction and real estate, and at the five per cent level in Trade and commerce. Thus the estimates support the hypothesis of higher failure rates in three of six industry groups, which together comprise approximately one-third of firms in the sample. The most substantial exception to this result is the Utilities and transport sector, in which failure rates are in any event low for both types of firm.

Estimates in column 2 include financial variables in addition to the industry-liability 
dummies. Independent variables in this case are linear and quadratic terms in firms' nominal capital (CAPITAL), the number of shareholders (SHRHLDR), and the share-price denomination at issue (DENOM). These financial variables may directly influence the decision to wind up the firm, through their effects on the incentives of decision-makers and on the agency problems between shareholders and creditors. Financial variables may also be indirectly relevant, to the extent that they serve as signals of firm value to uninformed investors, as some commentators have suggested. ${ }^{28}$ For this reason, financial variables may be endogenous to the failure event and estimated coefficients biased. This may explain why estimated coefficients for the financial variables are small in absolute value and not significantly different from zero. Estimates of the probability change associated with adopting limited liability remain positive in the three industry categories identified above, but are somewhat smaller than when financial variables are excluded. Although the coefficients are estimated less precisely in this case, they are significantly positive at the ten per cent level in both the Manufacturing and Trade industries.

Results reported in the last column of Table 2 also include a dummy variable for firms established after 1854 (DNEW). To the extent that more recently established firms are more likely to fail and also more likely to adopt limited liability, then estimated coefficients for liability status are biased upward when DNEw is excluded. The results in column 3 support this conjecture. Newer firms in the sample are estimated to be 15 per cent more likely to fail at the means of the data, which is significantly different from zero at the five per cent level. Estimated coefficients for the industry-liability dummies are smaller in this case and statistically insignificant in all but the Trade and commerce industry.

Thus the analysis provides only partial support to the hypothesis that limited liability firms were more prone to failure in the period following the 1856 reforms. While this evidence is suggestive of adverse selection in the choice of liability status, at least in some sectors, it is scarcely definitive. In particular, the reduced-form estimation procedure fails to distinguish between the direct effects of liability status on the exit decisions of firms and the selection effects, which might be driven by entrepreneurs' private information about default probabilities. Distinguishing selection and direct effects would, however, require separate identification of the determinants of liability status, which is difficult given the data available and beyond the scope of this paper.

\section{Conclusion and implications}

Our analysis of the the effects of liability rules on adverse selection in credit markets derives from the observation that the the English reforms of 1856 did not effect a sharp change in the nature of English capital markets, but rather were one part of a broader, more evolutionary development of corporate capital markets. Typically, authors have studied liability reform as the introduction of a completely new form of corporate organization. But, in fact, limited liability was available to entrepreneurs prior to reforms in England, albeit only with difficulty and perhaps at great expense. In the model developed here, therefore, liability reforms are represented by a change in the parametric cost of incorporation. This distinction is important, inasmuch as incorporation costs assume crucial importance in the model as a determinant of the degree of equilibrium adverse selection,

\footnotetext{
${ }^{28}$ See Section 3 above.
} 
and so of equilibrium interest rates and rates of investment.

The slow rate of adoption of limited liability among large British enterprises in the period immediately following reforms also prompts a search for models of the dynamic process of transition between the more primitive financial arrangements of the early Industrial Revolution and modern, corporate capital markets. The historical reluctance of existing firms to incorporate suggests the traditional view of the success of limited liability is a deficient one. The expectations of English investors regarding default rates of limited companies apparently played a crucial role in determining interest rates and availability of capital for limited firms. Given the existence of multiple equilibria for investors' beliefs about default rates, the model presented here admits complex dynamics for the beliefs of investors and the actions of entrepreneurs. We suggest that such a process may better describe the historical experience of nineteenth century Great Britain, and that the implications of the model for welfare, growth, and efficiency are considerably different from those derived from traditional transaction-cost models.

Our model also provides a new explanation of why limited liability was initially embraced by many firms in some industries, but by very few firms in other industries. To the extent that the risk of the various firms in a particular industry is correlated, investors would use their experience with the securities of early limited companies in the industry to update their priors about default rates of competing firms. Thus there may exist complementarities in the incorporation decisions of firms in an industry, and equilibrium may be characterized by widespread adoption of limited liability or by a paucity of limited firms.

Finally, this analysis offers another perspective on the differing paths of development of financial markets and institutions in Great Britain and other nations in the nineteenth century. It has been noted that the development of corporate debt markets and other forms of financial intermediation was slower in Great Britain than in competing countries, which some commentators suggest led Britain to "miss" the second Industrial Revolution. One interpretation of our theory is that Britain's earlier industrial success may have led to a build-up of retained earnings among firms, allowing owners of existing, profitable ventures to delay the incorporation decision. This contributed to the problems of adverse selection in limited liability debt markets and induced a development trap for British firms. 


\section{References}

CARr, J. L. And G. F. MAthewson (1988): "Unlimited liability as a barrier to entry," Journal of Political Economy, 96, 766-784.

ForBes, K. L. (1986): "Limited liability and the development of the business corporation," Journal of Law, Economics, and Organization, 2, 163-177.

Halpern, P., M. Trebilcock, and S. Turnbull (1980): "An economic analysis of limited liability in corporation law," University of Toronto Law Journal, 30, 117-150.

Hannah, L. (1976): The Rise of the corporate economy, Methuen, 2nd edn.

Heaton, H. (1948): Economic History of Europe, Harper and Brothers, revised edn.

Hellwig, M. F. (1981): "Bankruptcy, limited liability, and the Modigliani-Miller theorem," American Economic Review, 71, 155-170.

JEFFERYs, J. (1948): "The denomination and character of shares, 1855-1885," Economic History Review.

Manne, H. G. (1967): "Our two corporation systems: Law and economics," Virginia Law Review, 53, 259-284.

Meiners, R. E., J. S. Mofsky, And R. D. Tollison (1979): "Piercing the veil of limited liability," Delaware Journal of Corporate Law, 4, 351-367.

Milgrom, P. And J. Roberts (1994): "Comparing equilibria," American Economic Review, 84, 441-459.

PAyne, P. L. (1978): "Industrial entrepreneurship and management in Great Britain," in The Cambridge economic history of Europe, eds. P. Mathias and M. M. Postan, vol. VII, Cambridge University Press, pp. 180-230.

Pollard, S. (1994): "Entrepreneurship," in The Economic History of Britain Since 1700, eds. R. Floud and D. McCloskey, vol. 2, Cambridge University Press, second edn., pp. 62-90.

Posner, R. A. (1976): "The rights of creditors of affiliated corporations," University of Chicago Law Review, 43, 499-526.

Shannon, H. A. (1931): "The coming of general limited liability," Economic History, 2, $267-291$.

Shannon, H. A. (1932): "The first five thousand limited companies and their duration," Economic History, 4, 290-307.

Shannon, H. A. (1933): “The limited companies of 1866-83," Economic History Review, 4, 290-3.

ShiLts, W. (1992): "How deep the pool? Gains from general limited liability in Britain," Discussion paper, University of Iowa. 
Stiglitz, J. E. (1969): "A re-examination of the Modigliani-Miller theorem," American Economic Review, 59, 784-793.

Supple, B. (1977): "The nature of enterprise," in The Cambridge economic history of Europe, eds. E. E. Rich and C. H. Wilson, vol. V, Cambridge University Press, pp. $394-461$.

WoOdWARD, S. E. (1985): "Limited liability in the theory of the firm," Zeitschrift für die gesamte Staatswissenschaft, 141, 601-611. 